\title{
The Performativity of State Non-Recognition in Sports: The Case of Spain over Kosovo
}

\author{
FERNANDO GUTIÉRREZ-CHICO AND IÑIGO GONZÁLEZ-FUENTE
}

\section{$S$ sciendo}

Politics in Central Europe (ISSN: 1801-3422)

Vol. 17, No. 3

DOI: 10.2478/pce-2021-0018

\begin{abstract}
This article focuses on the use of sport by the Spanish Government to perform its non-recognition of Kosovo's statehood. Our main goal is to analyse the practices and narratives through which Spain's public authorities have carried out this policy in the sporting arena. Likewise, we set two specific objectives: to examine the administrative measures adopted by the Spanish government when a Kosovan team has participated in an event hosted in Spain; and to describe the policies and discourses regarding the display of Kosovo's national symbols in these competitions. The study is based on a qualitative approach of five major tournaments that have taken place (or due to) in Spain between 2018 and 2019. The documentation has been mainly gathered through desk-research. The three major data sources have been media press releases, Spanish Government's communiqués and sporting federation's statements. We underline that the policies adopted by the Spanish authorities respond to a systematic strategy to give no room for a potential understanding of Kosovo as a sovereign state. Likewise, we highlight that Madrid's attitude towards the Balkan country must be understood keeping in mind its own internal politics, specifically the nationalist claims from Catalonia and the Basque Country.
\end{abstract}

Keywords: Sports diplomacy, Non-Recognition, Statehood, Performativity, Kosovo, Spain

\section{Introduction}

On 7 December 2020, all 55 Fédération Internationale de Football Association (FIFA)-affiliated national teams from the Union of European Football Associations (UEFA) knew their opponents to qualify for the next 2022 World Cup 
due in Qatar. Kosovo, included in the last pot, was one of them. Initially tied in group A, the Balkan side had to be relocated. The reason was the presence of Serbia, thus matching one of the pairs considered as prohibited clashes. For political reasons, the European Federation had set a series of nations that could not be drawn into the same group. That was the case of Kosovo versus Serbia. The former declared its independence from the latter in 2008. Ever since then, Belgrade has not recognised the statehood of its neighbour, considering it as an actual province of its territory. ${ }^{1}$

With all the above in mind, Kosovo was switched to group B where Sweden, Greece and Georgia were waiting together with Spain. From that moment on, the coverage of the event by the Iberian country's media changed from a sporting perspective to a political one. This was so because Madrid, like Belgrade, does not recognise Kosovo's statehood either. So many questions arose in the diplomatic field that it overshadowed the footballing subject itself. Such was the situation that the Spanish Ministry of Foreign Affairs, Arancha González Laya, had to intervene. The major concerns had to do with the very possibility of the Balkan side playing on Spanish soil, the display of symbols (mainly the use of the flag, anthem and emblems) and the issuing of visas to the Kosovo delegation.

The rationale behind these worries was the precedents regarding the attitude of the Spanish administration every time it hosted a sporting championship with Kosovan participation. The systematic series of setbacks imposed by the former led the International Olympic Committee (IOC) to speak out. It actually warned against the awarding of international competitions to Spain. In addition, this diplomatic row has become a recent core topic in the Spanish Congress of Deputies. In the last three legislatures, up to a third (5 out of 14) of the official questions aimed at the Government in relation with Kosovo were about sport. ${ }^{2}$ Specifically, these dealt with the measures taken by the authorities to allow or not the presence of the Balkan delegation as well as to respect or not the display of its national symbols. These figures allow us to anticipate that sport has served (and serves) as a major vehicle for the diplomatic relations between Spain and Kosovo in terms of state non-recognition.

Much has been written about the use of sport for political goals. In fact, much has been written about the use of sport by Kosovo in order to seek and achieve international recognition for its statehood (Brentin - Tregoures 2016; Giulianotti - Collison - Darnell - Howe 2016; Gauthier 2018; Pulleiro 2020; McGuinnes 2021). Supplementary, there is a wide scholarship regarding the subsequent

1 Other prohibited clashes for UEFA are: Kosovo vs. Bosnia and Herzegovina; Kosovo vs. Russia; Russia vs. Ukraine; Armenia vs. Azerbaijan; and Spain vs. Gibraltar (UEFA, 2020).

2 These legislatures have been: XII (07/2016 - 05/2019); XIII (05/2019 - 12/2019); and IV (12/2019 - Currently). These periods have had different ruling parties: the initial right-wing Partido Popular (People's Party) from 07/2016 to 06/2018; the successive left-wing Partido Socialista Obrero Español (Socialist Party) from 06/2018 to 12/2019; and the current left-wing coalition Socialist Party-Podemos from 12/2019 onwards. 
Serbian protests and its court actions (Vila - Demjaha 2019). On the contrary, there is a gap in relation to the research on the non-recognition of Kosovo's state in the sporting arena. That is, therefore, where we set our scope. We look at how the Spanish Government has taken its political stand in this issue to the stadia.

The main objective of our article is to analyse the practices and narratives through which the Spanish public authorities have performed (and perform) its non-recognition of Kosovo's statehood in the sporting arena. Aligned with this, we set up two specific objectives. On the one hand, to study the administrative measures adopted by the Spanish Government every time a Kosovan team or player has participated in a sporting activity hosted in Spain. On the other hand, to describe the policies and discourses used by the Spanish public authorities regarding the display of Kosovo's national symbols in international competitions undertaken in Spain.

This article is divided into five main parts. The first one focuses on the methodology used for this research. After this, we set up a social-historical context of the relations between Spain, Serbia and Kosovo. It pays attention to the change of the Spanish foreign policies after Kosovo's independence from Serbia in 2008. The third section provides a theoretical framework. It presents an understanding of 'performativity' as applied to sports representation following Butler (1990/2007), Hobsbawm (1992) or Aquino (2017), among others. It also introduces some key ideas regarding sports diplomacy and counter-(para)diplomacy, the employment of sport by Kosovan authorities to seek and achieve international recognition and the symbolism attached to these policies. Following this, we proceed with the research findings and its discussion. We split them up into two main blocks. The first one looks at the administrative clashes between the Spanish authorities and the Kosovan delegations as for the recognition of Kosovo's passports and the issuing of the corresponding visas. The second one pays attention to the dispute over the display of Kosovo's national symbols during the tournaments held in Spain. Finally, we end with a series of conclusions. We underline that the policies adopted by the Spanish authorities respond to a systematic strategy to give no room for a potential understanding of Kosovo as a sovereign state. Likewise, we highlight that Madrid's attitude towards the Balkan country must be understood keeping in mind its own internal politics, specifically the nationalist claims from Catalonia and the Basque Country.

\section{Methodology}

This paper examines the administrative and symbolic struggles through which the Spanish public authorities have performed its non-recognition of Kosovo's statehood in the sporting arena. To do so, we analyse some specific events that have taken place (or due to) in Spain. The selected competitions are the 2018 Mediterranean Games (Tarragona/Catalonia); the 2018 European Junior and 
U23 Weightlifting Championships (initially due in the North-western region of Galicia); the 2018 World Karate Championships (Madrid); the 2019 UEFA U17 European Championship qualifiers (initially due in the Region of Valencia); and the 2019 Men's Junior World Handball Championship (Galicia). There is also the individual case of the basketball player Justin Doellman, whose potential use of the Kosovar passport in the Spanish league opened a diplomatic row.

The study is based on a qualitative approach. The documentation has been mainly gathered through desk-research. We have collected an overall of 26 files. Following the content analysis guidelines described by Skalski, Neuendorf and Cajigas (2017), the major data sources have relied on three big categories: a) a wide range of Spanish and international media press releases (16 files), b) the Spanish Government's communiqués and parliamentary requests (6 files) and c) sporting federations' statements and posts (4 files).

During these competitions, different agents acted and reacted to diplomatic measures on and off the stadium. Thus, the information employed for this article corresponds with the Spanish public authorities, political parties and high representatives of the different sporting federations and the National Olympic Committee; Kosovan delegations and the National Olympic Committee; and international sporting bodies, such as the International Olympic Committee (IOC). This way, it has been possible to closely study the narratives and practices of the Spanish administration regarding the non-recognition of the Balkan country in the sporting arena. Once the information was collected, we worked on a classification with these topics (structured in a matrix - see Table 1): event; date and place; organising/involved agents; context; performing event; and elements (symbols).

\section{Table 1: Spanish administration measures on Kosovo's sporting participations}

\begin{tabular}{|c|c|c|c|}
\hline Event & Date and Place & Agents involved & $\begin{array}{l}\text { Elements } \\
\text { (Symbols) }\end{array}$ \\
\hline $\begin{array}{l}\text { Mediterranean } \\
\text { Games }\end{array}$ & $\begin{array}{l}22 \text { June - } 1 \text { July } 2018 \text { - } \\
\text { Tarragona (Catalonia). Initially } \\
\text { due to } 2017\end{array}$ & $\begin{array}{l}\text { - ICMG } \\
\text { - COE } \\
\text { - Ministry of Foreign Affairs } \\
\text { - Tarragona's City Hall } \\
\text { - Catalonian Government }\end{array}$ & $\begin{array}{l}\text { - Visa } \\
\text { - Kosovo's flag }\end{array}$ \\
\hline $\begin{array}{l}\text { European } \\
\text { Junior and U23 } \\
\text { Weightlifting } \\
\text { Championships }\end{array}$ & $\begin{array}{l}\text { Initially due 20-27 October } \\
2018 \text { in Galicia }\end{array}$ & $\begin{array}{l}\text { - IWF } \\
\text { - CSD } \\
\text { - Ministry of Foreign Affairs } \\
\text { - Ministry of Sports } \\
\text { - Spanish Weightlifting } \\
\text { Federation }\end{array}$ & - Visa \\
\hline $\begin{array}{l}\text { Men's Junior } \\
\text { World Handball } \\
\text { Championship }\end{array}$ & 16-28 July 2019 in Galicia & $\begin{array}{l}\text { - IHF } \\
\text { - RFEB } \\
\text { - CSD } \\
\text { - Ministry of Foreign Affairs } \\
\text { - COE }\end{array}$ & $\begin{array}{l}\text { - Visa } \\
\text { - Kosovo's anthem } \\
\text { and flag }\end{array}$ \\
\hline
\end{tabular}




\begin{tabular}{|c|c|c|c|}
\hline Event & Date and Place & Agents involved & $\begin{array}{l}\text { Elements } \\
\text { (Symbols) }\end{array}$ \\
\hline $\begin{array}{l}\text { World Karate } \\
\text { Championships }\end{array}$ & 6-11 November 2018 in Madrid & $\begin{array}{l}\text { - WKF } \\
\text { - RFEK } \\
\text { - Ministry of Foreign Affairs } \\
\text { - CSD } \\
\text { - COE } \\
\text { - COI } \\
\text { - Spanish Presidency }\end{array}$ & $\begin{array}{l}\text { - Visa } \\
\text { - Kosovo's anthem } \\
\text { and flag } \\
\text { - Kosovo's name }\end{array}$ \\
\hline $\begin{array}{l}\text { UEFA U17 } \\
\text { European } \\
\text { Championship } \\
\text { qualifiers }\end{array}$ & $\begin{array}{l}\text { Initially due 20-26 March } 2019 \\
\text { in the Region of Valencia }\end{array}$ & $\begin{array}{l}\text { - UEFA } \\
\text { - RFEF } \\
\text { - CSD } \\
\text { - Ministry of Foreign Affairs }\end{array}$ & $\begin{array}{l}\text { - Kosovo's anthem } \\
\text { and flag }\end{array}$ \\
\hline Doellman case & Mid 2016 - Barcelona & $\begin{array}{l}\text { - FC Barcelona } \\
\text { - CSD } \\
\text { - ACB } \\
\text { - RFEB } \\
\text { - Ministry of Foreign Affairs }\end{array}$ & - Kosovo Passport \\
\hline
\end{tabular}

Source: Own elaboration

\section{Social-historical context}

The connections between Spain and the Western Balkans date back to long ago. In the context of this research, it is interesting to underline that sport has been one of the main elements of this bond. On the one hand, the matches between their respective male national teams in football, basketball and handball have had a large following within their corresponding populations through the media (Maura 2013: 183; Ferrero-Turrión 2020a: 13). On the other hand, there have been many and relevant Balkan professional players and coaches that have joined the major Spanish sporting competitions: Pedja Mijatovic and Radomir Antić (football), Aleksandar Đorđević and Željko Obradović (basketball) or Veselin Vujović and Branislav Pokrajac (handball), to name a few.

After the break-up of the former Yugoslavia in 1992, the Spanish foreign policy towards the Western Balkans was shaped by the guidelines of the international institutions (EU, UN, NATO). However, a new point of inflection happened on 17 February 2008 when the territory of Kosovo unilaterally declared its independence from Serbia. That was the beginning ${ }^{3}$ of a conflict that lasts until today and that pits the Kosovan Government against the Serbian minority living in the territory as well as against Serbia itself, which claims the sovereignty of that province. From the Spanish perspective, this unilateral independence declaration brought a series of actions by the Government of Spain related to

3 We point out here specifically the beginning of conflictual context associated with the declaration of independence of Kosovo. Of course, a larger contextualisation cannot ignore the ethnic cleansing policy undertaken by the Serbian government in Kosovo in 1999 (Díez Romero 2013: 602). 
the non-recognition of Kosovo as an independent country. This decision was announced quickly by the Ministry of Foreign Affairs. Specifically, one day later, on 18 February 2008. It is quite likely that the promptness of the Spanish response should be contextualised regarding the call for general elections in Spain due three weeks later, on 9 March 2008. Likewise, it is noteworthy that the Minister responsible for the almost immediate Spanish reaction, the social-democrat Miguel Ángel Moratinos, has a relevant political-diplomatic background linked to Serbia. Actually, he obtained the distinction of Honorary Citizen of Belgrade in 2009. Since then, Spain started a gradual but relatively fast withdrawal of most of its military and civic troops in Kosovo, which came to an end in October 2010 and March 2011, respectively. This way, Spain broke up its traditional alignment with the international community, which mostly recognised Kosovo, and opted for unilateral channels matching, in this case, with four more EU countries (Slovakia, Cyprus, Greece and Romania) and other states with important interests in the area like Russia, China, India, Brazil or South Africa.

Spain's official version of non-recognition of Kosovo, delivered by the social-democrat led government, addressed that the unilateral declaration of independence 'was a serious violation of the 1244 UN Security Council resolution and the territorial integrity of Serbia' (Vila - Demjaha 2019: 74). However, when the International Court of Justice decided in 2010 that Kosovo's declaration of independence was in accordance with international law, and the successive Spanish governments (with different ruling ideologies and parties) held their alignment with Serbia, it turned out to be obvious that there were and still are powerful reasons for such a political decision.

Following this line, some scholars (Borgen 2010; Díez Romero 2013; Ferrero - Turrión 2020b; Maura 2013; Vila - Demjaha 2019) interpret this non-recognition looking at Spain's Home Policies. Particularly, the rise of pro-independence claims in Catalonia for the last decade and, to a larger extent, the existing territorial debate within Spain about the historical nationalities of the Basque Country and Catalonia. These count on major political parties, with a wide representation in their corresponding councils, whose demands are oriented towards achieving an independent and sovereign state for their lands. Thus, in an interview with a Kosovan newspaper in 2009, Miguel Ángel Moratinos highlighted that the Spanish non-recognition of Kosovo responded to 'principles related to Spain's Basque and Catalonia autonomous communities'. Three years later, it was the by-then Prime Minister Mariano Rajoy who justified Spain's stand by underlining 'internal factors' (Ferrero - Turrión 2020b: 9). In fact, researchers like Vila and Demjaha (2019: 79-85) understand that the Spanish position of not recognising Kosovo 'gave the Catalan separatists a window of opportunity to create a (faulty) parallelism between the two cases'. In fact, when the Catalan Regional Council (Parlament de Catalunya) declared 
independence unilaterally on 27 October 2017, the international community, including Kosovo, declined to recognise Catalonia.

This situation of non-recognition has led to specific actions by the successive governments of Spain for the last decade. In practical terms, the most controversial decisions have gone from rejecting any diplomatic relation with Kosovan authorities (including the opening of an office in the capital, Pristina) to not recognise the Kosovan passport. This is somehow striking since, for instance, 'Kosovo's citizens can enter Serbia with a simple ID or Russia following a visa application' (Vila - Demjaha 2019: 80). Actually, the more present the Catalan pro-independence debate is in Spain Home Affairs, the more radical the stand of the different governments of Spain become regarding the recognition of Kosovo (Ferrero-Turrión 2020b: 9). Symbolically, the Executive branch led by Mariano Rajoy did not attend the EU-Western Balkans Summit in Sofia in May 2018. Besides, and related to this investigation, it started voting against the incorporation of Kosovo to international organisations like UNESCO or FIFA. Anyway, the IOC had already recognised Kosovo back in 2014, so its athletes began to participate in different sporting competitions after that. Furthermore, in November 2018, during the aforementioned World Karate Championships in Madrid, the Spanish Government banned the display of Kosovo's flag, anthem and emblems. This fact, together with a bunch of similar ones, inspire the reflections of the present article.

\section{Theoretical framework}

We consider the theory of performativity as a relevant framework to develop our analysis of how the Spanish Government performs its non-recognition of the Kosovar State through sport. This concept owes its settlement to the work of Butler (1990/2007) and her studies on gender. According to her, there is no sexed subject that learns gender roles. On the contrary, the person constitutes him/herself through performance. Given that gender implies a series of behaviours and actions, Butler points out that these have to be redefined whilst building up some others socially authorised. This way, one can be what s/he wants in any situation. Consequently, the body becomes performative by creating a sense of reality through transformation. The sum of these actions would hold a potential change in social and power relations. As she underlined, gender is 'the stylized repetition of acts' over time (Ibid.: 192).

In our particular case study, we follow Aquino's (2017) understanding of this theory. She understands that the 'national body' is represented through sporting actors. 'The nation is no longer being something fixed or abstract: it is enacted through the calling-up of athletes to play for the national team, the way those athletes present themselves, the media responses to those presentations, and those athletes' performances on the pitch' (Ibid.: 124). Previously, Hobsbawm (1992) had already done a similar approach by highlighting the efficacy of sports 
as a means in the construction of the national feeling. According to him, these disciplines have the capacity of shaping (players, managers, fans, symbols, etc.) something as abstract as the nation. Therefore, he underlines that 'the imagined community of millions of beings seems more real under the form of a team of eleven people whose names we know' (Ibid.: 152-153).

It is within this context how scholarship has theorised about some of the social aspects of sport. More specifically - although not only - about its role as a reflective arena in which to represent all those issues (social, political, religious, etc.) happening in its surrounding environment (Giulianotti 1999; Pulleiro 2015). As for the political stand, we may encounter a wide range of examples through recent history such as the Argentina-England quarter-finals match at the 1986 football World Cup, with the 1982 Falkland/Malvinas War in the background; or the chess games between the US player Bobby Fischer and his Soviet counterpart Boris Spassky at the climax of the Cold War.

This symbolic understanding of the sporting arena allows us to explain our case study and to better discuss the measures taken by the Spanish Government regarding Kosovo's participation in international competitions. Since its independence from Serbia in 2008, Kosovo has turned to sports in order to seek international recognition for its statehood (Brentin - Tregoures 2016; Giulianotti - Collison - Darnell - Howe 2016; Gauthier 2018; Pulleiro 2020; McGuinnes 2021). The reason for this, following authors like Brentin and Tregoures (2016), Gaulthier (2018) or McGuinnes (2021), has been that Kosovo's attempts to find such recognition through traditional means have failed. It has been due, partly, to the opposition of Serbia and all those countries, like Spain, with potential breakaway territories.

This particular strategy responds to the so-called 'sports diplomacy'. As Lin, Lee and Nai (2008: 26) state, 'very often the objective of sports diplomacy is simply to seek acknowledgement of their existence within the international system'. This is due to the global impact and the potentiality of representation of the different sporting disciplines in a common and shared arena (Murray - Pigman 2014). Indeed, it is this symbolism that makes sport work as a 'catalysing motor' (Brentin - Tregoures 2016: 362) for international recognition purposes. This is why scholarship has pointed out the relevance of this scenario for newly established or unconsolidated territories whose statehood and/or recognition goes under strong contestation (Houlihan - Zheng 2015; Giulianotti - Collison - Darnell - Howe 2016). This seems to be the case of Kosovo. However, we agree with Brentin and Tregoures (2016) that sport does not substitute classic international diplomatic procedures, but rather supplement them. Therefore, Kosovo's efforts via 'the sport's door' (Ibid.: 361) pursue an ultimate and clear goal, which is to enter the UN.

Whether closer or not to full membership in the UN, Kosovo's efforts to obtain international recognition through sporting means have already had 
relevant effects. Arguably, the biggest achievement in this aspect took place on 9 December 2014. On that day the IOC recognised Kosovo's National Olympic Committee (NOC). Consequently, apart from entering this worldwide organisation, it meant the recognition of Kosovo as an independent competitor. In other words, its athletes could participate, from then on, in international events representing Kosovo. Let us not forget that, until then, these sportsmen and sportswomen had to play under the umbrella of other countries, mainly Serbia and Albania.

In addition, according to Brentin and Tregoures (2016), the IOC's decision brought two other significant consequences. On the one hand, it endorsed a global understanding of Kosovo as a state recognised by the international community, with potential effects in the political arena. On the other hand, it opened the door for further membership throughout the different sporting federations, thus broadening Kosovo's acceptance in the worldwide stage. In fact, the latter had been in place before 2014. Some international bodies had already accepted Kosovo's national federations in sports such as table tennis (2003), weightlifting (2008), archery (2011) or judo (2012) (McGuinnes 2021). Notwithstanding, the wider waterfall of sporting recognitions - both in number (quantity) and social transcendence (qualitative) - came after the IOC's move. Thus, Kosovo's national federations were also included in tennis (2015), cycling (2015), basketball (2015), athletics (2015) or volleyball (2016), among others (Brentin - Tregoures 2016; McGuinnes 2021). Another milestone in this recognition process came through football, given its dominant role in the sport scenario. In May 2016, Kosovo's Football Federation was admitted firstly to the UEFA, and later on that same month to the FIFA. Therefore, this inclusion allowed Kosovo to access the qualifying rounds for the successive Euro and World Cups, thus widening its international exposure.

The memberships listed above also involved a meaningful relevance in symbolic terms. According to the Olympic Charter (IOC 2020), the national federations have to be politically independent from their state governments. This means that in international sporting events the sides actually do not represent their states, but their national federations or National Olympic Committees (NOC). Nonetheless, as Gaulthier (2018: 231) states, 'sporting federations often use their state's flag in their logos, and the state's anthem plays at events'. This leads to an eternal-like discussion since these sporting federations do not always correspond with an actual state. This state-or-nation puzzle responds to certain ambiguity when defining a country. As Gaulthier (2018: 237) points out, up until 1996 the IOC defined country as 'any country, state, territory or part of a territory which the IOC in its absolute discretion considers as the area of a recognised NOC'. However, as of that year, the IOC reviewed the definition to be 'an independent state recognised by the international community' (Ibid.: 237-238). In other words, as Pulleiro (2020: 4) highlights, the IOC 'delegates 
the recognition of NOCs mainly to the UN, and at the same time, the recognition of NOCs is limited to those states that emerge from secession processes supported by the international community'.

Notwithstanding, this favourable performativity of sports diplomacy may also encounter its opposite in terms of blocking practices and measures. In this sense, we consider the concept of 'counter-diplomacy' as a very relevant framework. As Barston (1988/2006: 4) states, 'for some the purpose of "counter-diplomacy" is the use of diplomacy to evade or frustrate political solutions or international rules. Counter-diplomacy seeks the continuation or extension of a conflict'. This, from the understanding of the Spanish administration about Kosovo's status, can extend to the newly coined 'counter-paradiplomacy'. It refers to the reaction exercised by a parent state against a paradiplomacy ${ }^{4}$ perceived as opposing to its own interests (Castán Pinos - Sacramento, 2019).

Counter-(para)diplomacy can specifically aim at preventing certain territories from gaining international recognition as a state. As Ker-Lindsay (2020) underlines, this counter-recognition evolves over time and the different strategies must integrate a wider plan considering the conflict as a whole. Sport has been used as part of these policies. One of the most studied cases has been the row between China and Taiwan. In the 1950s, the former tried to expel the latter from the Olympic movement. This was so since Beijing considered Taipei as part of its sovereignty, thus not recognising its statehood. As Pulleiro (2020) explains, although this goal initially failed, it only worked as of the 1970s once the correlation of power was favourable to China (given its new status as a nuclear power). From then on, the IOC assumed the new Chinese political reality and changed Taiwan's sporting status following the One-China policy (Ibid. 2020), which implied a non-recognition of Taipei's statehood. This was officially addressed in the so-called Nagoya Resolution.

We can also observe this when it comes to competitions hosted by countries who do not recognise Kosovo's statehood. As Giulianotti, Collison, Darnell and Howe (2016) mention, the Russian hosts of the 2016 European Judo championships refused to recognise the Kosovar status of the female winner, Majlinda Kelmendi. The International Judo Federation (IJF) had to intervene in order to find a solution, which ended up in raising both the Russian and the Kosovar flags together at the medal ceremony. Other examples are the prohibition of displaying Kosovo's flag at any venue during the 2018 Football World Cup hosted in Russia (although Kosovo did not participate), or being prevented from including Kosovo and Serbia in the same qualifying group.

4 The term 'paradiplomacy' (derived from parallel diplomacy) aims at the international engagement of sub-state governmental actors (Aldecoa - Keating, 1999). In this case, Spain would not be the parent state (that would be Serbia). However, given its non-recognition of Kosovo, the latter is still seen as a sub-state. 
These setbacks have also found its reflection in the administrative scenario. Thus, sporting events include not only the performances on the field, but also press coverage and the relocation of athletes to the host country. In this sense, some states have found a balance to allow Kosovar sportspeople to enter the country without major restrictions while keeping their non-recognition of the Kosovar state. Such is the case of Brazil and the celebration of the 2016 Olympic Games in Rio de Janeiro, which saw the athletes of the Balkan country travelling to the South American nation with their Kosovar passports. The agreement, on this occasion, was the expedition of temporary visas by the Brazilian authorities (Brentin - Tregoures 2016). On the contrary, some other administrations have made things tougher and have made their statehood viewpoint prevail. This was the case, as Giulianotti, Collison, Darnell and Howe (2016) compile, of a handball tournament hosted by Ukraine. That time, some Kosovar journalists complained about the impossibility to obtain a visa to enter the country and broadcast the matches of their national team.

Spain, whose administration does not recognise Kosovo's statehood, has also starred in some of the most echoing administrative and symbolic clashes in the sporting arena regarding the participation of the Balkan country. Hence, our work aims at analysing the practices and narratives how this non-recognition has been performed in a series of sporting events hosted on Spanish soil.

\section{No visa, no symbols, no state}

Based on our analysis, we present the following results divided into two main aspects. The first one focuses on the legal and administrative clashes between the Spanish State (and its diverse institutions) and the different Kosovar sporting delegations. It goes from rejecting the entry of athletes with Kosovar passports - as these are not recognised - to a series of agreements whereby these sportspeople are authorised to enter the Spanish territory through a particular visa called hoja aparte (sheet aside). The second one looks at the symbolic dispute regarding the display and use of Kosovo's emblems (flag, anthem, name, etc.) on Spanish soil. This shows the efforts and strategies employed by both sides to highlight and impose their political aims.

However, the Spanish performativity of non-recognition of Kosovo's statehood through sports starts with a series of clashes that go beyond bureaucracy and symbolism. It has to do with the initial attempts of the Spanish state to ban the very participation of Kosovo in international events hosted throughout the Iberian country. One of the main examples of this position took place along the preparations for the 2018 Mediterranean Games. ${ }^{5}$

5 The $18^{\text {th }}$ edition of the Mediterranean Games was supposed to happen in 2017. However, they had to be postponed due to funding problems and the political turmoil in Catalonia. 
In October 2011, the International Committee of the Mediterranean Games (ICMG) chose Tarragona (Spain) as host city. Let us not forget that Tarragona is located in the region of Catalonia, where nationalist aspirations are high and whose Regional Council voted and declared its unilateral independence from Spain in October 2017. By the time of the election, Kosovo's Olympic Committee had not yet been approved and accepted by the IOC. This incorporation happened in 2014. Consequently, this movement changed the Spanish expectations since the Balkan country would be able to participate in the aforementioned event from then on. As for that moment, the Spanish diplomacy sought to avoid Kosovo's presence in Tarragona. In this sense, a first meeting held in mid-2015 voted against the participation of this newly recognised NOC. However, its eligibility for the event became a reality in October that year when the ICMG admitted it following pressure from the IOC and the European Olympic Committee (Mackay 2016).

As long as the celebration of the 2018 Mediterranean Games was approaching, this political tug-of-war was increasing. Another milestone occurred in March 2017. At that time, the Spanish Olympic Committee (COE) proceeded to change its statutes. This caught the attention of both the Spanish Ministry of Foreign Affairs and the Sports High Council (CSD) as it made clear that Kosovo could participate in the event. As Alejandro Blanco, COE's Chief, declared to the media, 'Kosovo participates because it has been recognised by the IOC and the Association of National Olympic Committees. The Mediterranean Games is a competition among Olympic Committees, not countries (...). We do not recognise Kosovo. It is the Olympic Committee. We are obliged to follow its decisions; (...) we depend on them. The IOC approves our statutes. But we never go against the Spanish Law' (Cifuentes 2017). In this aspect, Brownell (2008) underlines that the legal right to determine the invited participants lies on the IOC, rather than the host city. Hence, and according to the Olympic Charter, the IOC approves the list of NOCs competing in the event and the host city must comply with it, under punishment should the town act contrarily. In fact, as Brownell adds, the current regulation counts on the Nagoya Resolution ${ }^{6}$, which serves as a precedent to dictate what the role of the host city is in terms of inviting participants. This sort of challenge between the COE and the Spanish authorities ended up in the Congress, where the party Ciudadanos (Citizens) officially registered seven questions regarding the potential participation of Kosovo (Maura - Del Campo 2017). At that point, the government's response defined this possibility as 'hypothetical' and added that in case it happened 'it

6 The so-called Nagoya Resolution was the agreement adopted in 1979 between the Republic of China (China-Taipei in Olympic terms) and the People's Republic of China (PRC), whereby the latter returned to the Olympics. This consensus designated the symbolism under which the Republic of China would participate in future competitions (Brownell 2008). 
would not mean an implicit recognition of that territory by the Kingdom of Spain' (Congress of Deputies 2018).

\section{Administrative clashes}

In May 2016, the European Commission advocated a visa liberalisation for Kosovo. Should this suggestion have succeeded, it would have meant that citizens with Kosovar passports could enter the Schengen Area for short stays with no administrative restrictions (Giulianotti - Collison - Darnell - Howe 2016). To this day, this issue has not become a reality and still remains uncertain. However, it shows the willingness of the EU to carry on with the strengthening of relations with the Balkan country, thus providing a boost for its recognition as a state (Ibid. 2016). These sorts of administrative questions have not gone unseen by the Spanish authorities, whose strategies when dealing with Kosovar athletes have brought diplomatic and sporting consequences on and off the field.

Until that situation is resolved, Kosovar sportspeople need a visa to undertake tournaments on Spanish soil. Nonetheless, this bureaucratic step has become a big deal for both competitors and authorities. One of the first episodes took place in the prelude of the aforementioned Mediterranean Games. Once clear that the Balkan delegation could participate, it was time to proceed with the travelling paperwork. Spain does not recognise Kosovo as a state, therefore it does not award any validity to the passports or any other documents issued by the Balkan country ${ }^{7}$. Barely four months before the start of the event, the Spanish-born Deputy Director of the IOC, Pere Miró, stated in an interview with a Catalonian local radio that Spain was not issuing the requested visas. That information came after both the organisers of the Games and Kosovo's NOC warned the IOC about the Spanish government's attitude (Ràdio Associació de Catalunya 2018). Likewise, Miró also underlined that his organisation had sent a letter, some time before, to the Spanish Minister of Sports, with no response whatsoever (Ibid. 2018).

The counterattack from the Spanish authorities did not take long. Diplomatic sources spoke with several media outlets to express their willingness to issue the visas. However, they emphasised their 'surprise' about Miró's words since Schengen rules dictate that this paperwork 'must be requested three months before entering the territory', a timeline that had not yet occurred (Saumell 2018). This allusion to Schengen refers to the Regulation number 810/2009 of the European Parliament and of the Council of 13 July 2009 establishing a Community Code on Visas. In its second chapter regarding the application procedure, Article 9 points out the practical modalities for lodging an application. It states that these

7 At this point, we shall remember that many Kosovar athletes count on double nationality (Kosovar plus another one). This is due to their ethnic background or for refugee/political asylum reasons motivated by the Balkan War and its successive conflict in Kosovo. Consequently, these participants may have used an alternative passport to enter and play in Spain. 
'shall be lodged no more than three months before the start of the intended visit. Holders of a multiple-entry visa may lodge the application before the expiry of the visa valid for a period of at least six months' (The European Parliament and the Council 2009). ${ }^{8}$ The solution eventually adopted by the Spanish Ministry of Foreign Affairs was the issuing of the visas under the formula hoja aparte (sheet aside), with a validity for only as long as the Games took place. Additionally, it included an explicit clarification whereby it was highlighted that this administrative mechanism would not mean the recognition of Kosovo as a state.

This dispute over the visas has also brought some penalties to Spain. Parallel to the preparations for the Mediterranean Games, the Iberian country was getting ready to welcome another major international sports event: the 2018 European Junior and U23 Weightlifting Championships. Two years earlier, La Coruña (Galicia) had been chosen as host city by the European Weightlifting Federation (EWF). The tournament was due to happen in October 2018. However, six months before (April), the EWF sent an email to its Spanish counterpart informing them about their loss of hosting rights, which would move to Poland (Lambea 2018). The reason was the reluctance of the Spanish government to give visas to the Kosovar participants.

Prior to this decision, EWF's President, Antonio Urso, had sent a letter to both the Spanish Ministries of Foreign Affairs and Sports. In it, the federation sought some guarantees that the Balkan athletes would be allowed to take part in the tournament. The lack of response from the Spanish authorities, after the three weeks' time conceded, pushed the European institution to move forward and ban Spain from its organisation (Oliver 2018). For its part, the Spanish administration justified the nonresponse by stating that it made no sense ever since they had made it clear back in 2016 that no Kosovar nor Gibraltarian weightlifter would be accepted.

One of the alternatives exposed by the EWF was to try and find a decision similar to that of the Mediterranean Games. However, the Spanish government declined to do so. In this sense, CSD underlined to the press that the situation was not the same. According to this entity, the Mediterranean Games' organising committee depended on the IOC, so an exemption was possible. On the contrary, given the fact that the organising committee of the weightlifting championship depended on the Spanish authorities, these would have the final word as for who could participate (Nieto 2018). By highlighting so, CSD was referring to Title 2, Article 8 of the Spanish Law of Sport, which compiles the competences of this institution. In its point ' $i$ ', it states that CSD will 'authorise or deny, prior agreement of the Ministry of Foreign Affairs, the celebration on Spanish soil of

8 This regulation was modified on 2 February 2020. As of then, the new legislation adopted has been the Regulation number 155/2019 of the European Parliament and of the Council. Among its changes, it widens the lodging period, which can be up to six months before the start of the intended visit. 
official international sporting competitions, as well as the participation of Spanish national sides in international competitions' (Government of Spain 2018a). In fact, the utilisation of this very legislation pushed the Spanish squad not to take part in the 2017 European U15 \& U17 Weightlifting Championships. CSD incited the Spanish Federation to stay aside because Pristina, Kosovo's capital, was the host city.

Another chapter in this particular administrative row also took place by the end of 2018. Between 6-11 November, Madrid hosted the World Karate Championships after the Peruvian Karate Federation renounced the corresponding rights. One of the competing delegations was Kosovo. One of the many clashes with the Spanish organising committee had to do with the visas used by the Kosovar athletes. The Deputy Director of the IOC, in an interview with the Spanish press, accused the Iberian authorities of not providing the corresponding documents to the Kosovar athletes to participate in the tournament (EFE Agency 2018). According to Miró, this was the cause motivating that these sportspeople had to enter Spain with visas issued by the French government (which recognises the Balkan country statehood, and so its passport), as it actually happened. The Spanish Government's reply came almost immediately. The Foreign Affairs Minister rejected this information. In a public statement published by his Ministry, Josep Borrell underlined that 'no visa could be denied since no lodging has been received in the competent consular office, that of the Embassy of Spain in Skopje, by any Kosovar sportspeople' (Government of Spain 2018a). Likewise, one day later the Minister also announced the Ministry's intentions to formally report to the IOC after Miró's accusations. According to the statement, those affirmations 'lack foundation (...) and have caused a deep discomfort to the Spanish Government' (Government of Spain 2018b).

Following Hobsbawm (1992) and Aquino's (2017) understanding of athletes as performers of the nation, we observe the role of the Kosovar sportspeople in this controversy - as embodying the Balkan state by holding this specific passport. Therefore, the policies taken by the Spanish government as for the visas represent a performance of non-recognition. This has had effects on an individual basis too. In the summer of 2016, the US-born basketball player Justin Doellman became naturalised as Kosovar. This movement allowed him to play for the Balkan national side in continental and international tournaments. Likewise, his by-then team, Barcelona, saw itself favoured as Doellman would stop counting as a non-EU player. Far from reality, in the middle of this process CSD spoke out to warn about no validity whatsoever should Barcelona claim the player as Kosovar. CSDs' Director in 2016, Miguel Cardenal, declared to the local press that 'that passport [Kosovo's] in Spain has no validity because it is from a country that is not a country because it is not recognised by Spain, therefore neither this player nor any other could obtain a [sporting] license linked to a nationality that Spain does not recognise' (Herrero 2016). 


\section{Symbolic ban}

According to Elgenius (2011: 397), national symbols act as 'shortcuts to the group they represent'. In the same line, Gilboa and Bodner (2009: 460) stress that they serve as an 'identification of states'. Among these, the authors underline three main elements: the flag, the anthem and the emblem. To this list we shall add another variable: the name. Thus, we agree with Raento and Watson (2000) that a strategy of power is executed by challenging the existing names as well as by naming and renaming. A clear example of this was the aforementioned diplomatic row between China and Taiwan regarding the terms under which both would compete in the Olympic Games. This strategy of power has also happened with regards to the participation of Kosovar athletes in international sporting competitions taking place in Spain. The Spanish policy of Kosovo's statehood non-recognition has been performed in the symbolic field too. This has gone from banning the display of the national flag in venues and parades to forbidding the use of the country's name in tournaments.

One of the first major occasions to observe this was the 2018 Mediterranean Games hosted in Tarragona. Apart from the aforementioned issue with the visas, the utilisation of certain symbols created a new diplomatic row between both nations. This edition meant Kosovo's debut in this event. However, when observing both the opening and closing ceremonies this is not so clear. The reason for these doubts lies in the way the Balkan delegation was introduced in the Olympic Stadium. Contrary to the other 25 competing nations, which were presented with their country name, Kosovo was named after its NOC. Thus, following Raento and Watson (2000), the act of not showing Kosovo's name is a challenge aimed at denying its existence - a performance to prove how Spain does not recognise this particular state.

These parades also witnessed another symbolic controversy. The flag-bearers could not carry Kosovo's national flag as did the rest of the participating countries. Instead, they had to hold the NOC's, which includes a miniature version of the national flag above the Olympic Rings. ${ }^{9}$ The Balkan delegation reported that this limitation was imposed by the Spanish Government at the very last minute. In an interview with the press, Besim Hasani, president of Kosovo's NOC, declared that 'it was not part of the agreement. [...] Somehow we were forced to do it' (Barker 2018). The agreement Hasani refers to has to do with the ceremony carried out the day before. As tradition dictates, every delegation is welcomed in the Olympic Village by raising their respective flags, which remain on top for as long as the Games last. This time was no exception and every participating country did so. As Kosovo's NOC official Twitter account posted, ‘\#Kosovo flag

9 Interestingly, the flag-bearer in the Opening Ceremony, Herolind Nishevci, did not wave the emblem, as it normally happens in these sorts of rituals. He was escorted by two members who emphatically swung the national flag. 
raised for the first time in Mediterranean Village of @Tarragona2018. We are ready to write history! \#1DayToGO' (Kosovo Olympic Committee 2018). This tweet also included three pictures where Kosovo's flag appears on top of the pole together with the rest of the national emblems. Likewise, this polemic over the insignia also had its reflection in the official web of the Mediterranean Games. In the tab dedicated to the competing countries, every nation is portrayed with its state flag, but Kosovo. The latter is framed with the letters 'KOS' in white over a blue background (see Picture 1). Once again, we observe in this depiction a performance of non-recognition by avoiding the employment of the Kosovo flag. During the Games, Kosovo won four medals, three of which were gold. This meant that the corresponding prize ceremony had to face one more encounter with Kosovo's flag and anthem. This time, opposed to the previously explained, these emblems were displayed with no objection. Consequently, Catalonia witnessed the playing of an anthem whose state (Kosovo) is not recognised by the Spanish authorities.

\section{Picture 1: Depiction of Kosovo without national flag}

\section{COUNTRIES}

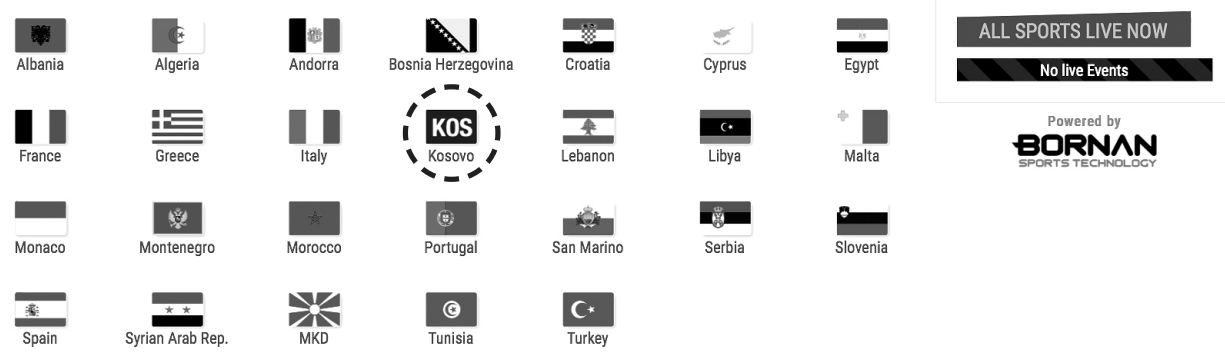

Source: Oficina dels Jocs Mediterranis Tarragona 2018 (2018).

The 2018 World Karate Championships hosted in Madrid represented another example of this strategy of power over the symbols between Spain and Kosovo. The latter was one of the competing nations, although this would be hard to affirm when looking at the official records. Based on the aforementioned competencies of the CSD, the Balkan delegation was banned from performing under the name of its country. Instead, the Kosovar karateka had to act under the World Karate Federation one. Thus, every time an athlete of this nation was involved in a practice, the scoreboard depicted him/her with the acronym WKF5. A similar prohibition went for the clothing. Kosovar participants were 
wearing tracksuits with the letters KKF, standing for Kosovo Karate Federation, since the name of the country could not be displayed either. We observe in this measure one more challenging act to deny the existence (non-recognition) of Kosovo as a state by the Spanish authorities (this time through the mandate of the CSD). This illustration proves the national symbolism attached to the sporting clothing (Juventeny 2019) and its social-cultural meaning. This was not the only emblem banned during the Championships. As with the Mediterranean Games, Kosovo's national flag was also prohibited. In fact, the limitations were stricter since it was not allowed at any moment. Consequently, the Kosovar karateka were represented with the WKF one. This had a responsive attitude by the Balkan team. Its participants, as performers of the Kosovar state, boycotted the opening ceremony by not showing up as a protest for the forbiddance.

This diplomatic tug of war extended beyond the end of the tournament. This umpteenth dispute together with the issuing of the visas (explained above) prompted several interventions from different organisations. One of the first institutions to speak out was the very World Karate Federation. Its Spain-born President, Antonio Espinós, told the media that 'for future events, we have to seriously consider the possibility of not coming to Spain because we cannot easily accept that the rights of one of our full members is refused' (Morgan 2018a). Stricter was the IOC, which threatened a potential blocking of international competitions in Spain. Its Spanish-born Deputy Director, Pere Miró, also used the media to warn the Iberian country. He stated that 'if the Spanish Government is not in the conditions to guarantee access not only to Kosovo but to every athlete to compete, we should warn all the International Federations that, until this is solved, they should not hold international competitions here [Spain]. [...] We cannot suspend a country and we cannot say they cannot organise events there, but we are totally ready to say that and this is what we will say now. International Federations, please, before awarding any competition, make sure you have all the guarantees that all athletes will be welcome in Spain' (Morgan 2018b). In this line, COE's President, Alejandro Blanco, pointed out that

what the IOC and the International Federations recognise are the Olympic Committees and the National Federations that register in the international organisations. That is it. When you register, you have to respect the Olympic Charter and the statutes of the federations. Otherwise, do not get registered. [...] Kosovo's federations and its committee are recognised by every international federation and by the IOC. Its athletes participate in every competition throughout the world. Except in Spain (Ojeda 2018).

Internal politics also got involved in this affair. The pro-independence nationalist-led Catalonian Government added some more pressure on the Spanish authorities by exhorting them to respect the international sporting agreements. Thus, 
the spokesperson of the Govern (Catalonian Government), Elsa Artadi, urged Pedro Sánchez (Spanish Prime Minister) 'to respect the Olympic Charter (...) not to risk international sporting competitions in Spain' (El Periódico de Catalunya 2018). We observe this appeal from Catalonia's institutions aligned with what Zabalo and Odriozola (2017) consider to be a new discourse on regional nationalism. For these scholars, these political parties have switched from revolutionary ideas and praxis (ethnic and cultural difference, mainly) to highlight the concept of democracy. Thus, the new proposals try to reach a balance between collective and individual rights. Therefore, the aforementioned claim becomes a challenge (from Catalonia to Spain in this case) to show who is more democratic (as a support to its pro-independence aspirations).

All these declarations happened, actually, during the promotional week of Spain Global Sports, an initiative aimed at consolidating the Iberian country as a solid venue for international sporting competitions. At the presentation event, another Spain-born member of the IOC, Juan Antonio Samaranch Jr., insisted on the necessity to respect Kosovo's national symbols if Spain opted to host future competitions. He stressed that 'we respect the right of any sovereign country to recognise the country it wants to recognise. That is not our business. What we like, and include in the Olympic Charter, is the defence of those athletes. If they cannot compete under their national flag, they should under their NOC's or their federation's' (ABC 2018).

A few days later, more accurately on 14 November 2018, IOC and COE published a joint statement. In it, both institutions express their satisfaction with the new measures adopted by the Spanish Government. It refers to the communiqué sent from the Spanish Government to COE's President, Alejandro Blanco, in which it agrees to respect Kosovo as a participating nation in sporting competitions held in Spain. Based on the IOC-COE's communiqué,

through this decision (...) the Spanish Government will provide the Kosovan sports delegations competing in Spain with the relevant visa and will authorise them to use their own national symbols, anthem and flag, in accordance with Olympic protocol. This will ensure that the athletes of Kosovo can participate under the same conditions as all the other athletes from the 206 National Olympic Committees recognised by the IOC (IOC 2018).

Immediately after, the Spanish Ministry of Foreign Affairs published another statement amending some of the information quoted by the IOC-COE. It stressed that

there has been no change in the Spanish stance. Spain has allowed and eased the participation of Kosovan athletes in those competitions, issuing the visa when lodged, always in accordance with the Olympic Charter and allowing the 
use of its symbols, flag and anthem based on Olympic protocol. In the future, it will keep doing it, regardless of its political stance of non-recognising the independence of Kosovo (Government of Spain 2018b).

Contrary to these words, COE's President pointed out that this agreement did represent a change in Madrid's position. Alejandro Blanco underlined that 'we respect any political stance of the government regarding Kosovo, but sportingly it is a great advance. Despite what [the Ministry of] Foreign Affairs says, they [Kosovan athletes] have never been allowed to compete in Spain under their flag and in the new agreements it is clear that now they can' (Cruz - Díaz - Guerra 2018). In this sense, we observe another strategy of power, this time over the utilised narrative, whereby the Spanish authorities give no space for a potential understanding of Kosovo as a legal state. Consequently, any aspect related with the Balkan country on the sporting arena is systematically calculated.

Despite this apparent consensus, a new dispute came out not long after. This time football was the rowing sport. The national sides of Spain and Kosovo were drafted into the same group for the UEFA U17 European Championship qualifiers. The Iberian country had the hosting rights, due between 20-26 March 2019, and so the towns of Benidorm and Alcoy (Region of Valencia, Eastern Spain) were chosen as venues. However, the last week of February 2019 UEFA decided to withdraw such a status and moved the corresponding matches to a neutral scenario: its training camps in Nyon (Switzerland). The reason was the Spanish government's refusal to display Kosovo's flag and anthem during the games. This setback from Madrid seemed to go against the respect of the Kosovan national symbols promised a few months earlier.

Between the agreement obtained with the IOC and this new episode, the Spanish Parliament discussed the sporting affairs affecting Kosovo's participation. Thus, the Catalonian nationalist political party Partit Demòcrata Europeu Català (European Catalonian Democratic Party) officially requested information about the potential damages, to both the Spanish international sport and the Olympic sport, of not recognising the Republic of Kosovo (Xuclà i Costa 2018). In its reply, the central government reiterated its 'willingness to allow the participation of Kosovan athletes in those international competitions taking place in Spain under the auspices of the IOC' (Congress of Deputies 2019). However, this did not clarify one aspect that turned out to be decisive to understanding UEFA's decision. As explained above, Madrid would make exceptions in those tournaments whose organising committee depended on the IOC. On the contrary, when the preparations depended on the Spanish authorities, in other words the CSD, this would set a series of prerequisites, amid which are the ban on Kosovan symbols. Consequently, the latter were the conditions that the Spanish Football Federation (RFEF) sent to its European counterpart regarding the framework within which this qualifying round would happen, prompting UEFA's move. 
In addition, following the IOC's threat to stop awarding international tournaments to Spain unless Kosovan symbols and rights were guaranteed, UEFA stepped further. By the time these matches were played in Switzerland, its Executive Committee held an ordinary meeting in Baku (Azerbaijan). Among its approved measures, it agreed on a new policy regarding countries not recognising Kosovo. In this sense, UEFA pointed out that those 'teams which cannot host Kosovo clubs or national teams on their territory ${ }^{10}$ may request to organise their home match on neutral ground. However, they will have to accept to play away matches in Kosovo' (UEFA 2019).

\section{Picture 2: Banner warning the non-recognition of Kosovo's statehood}

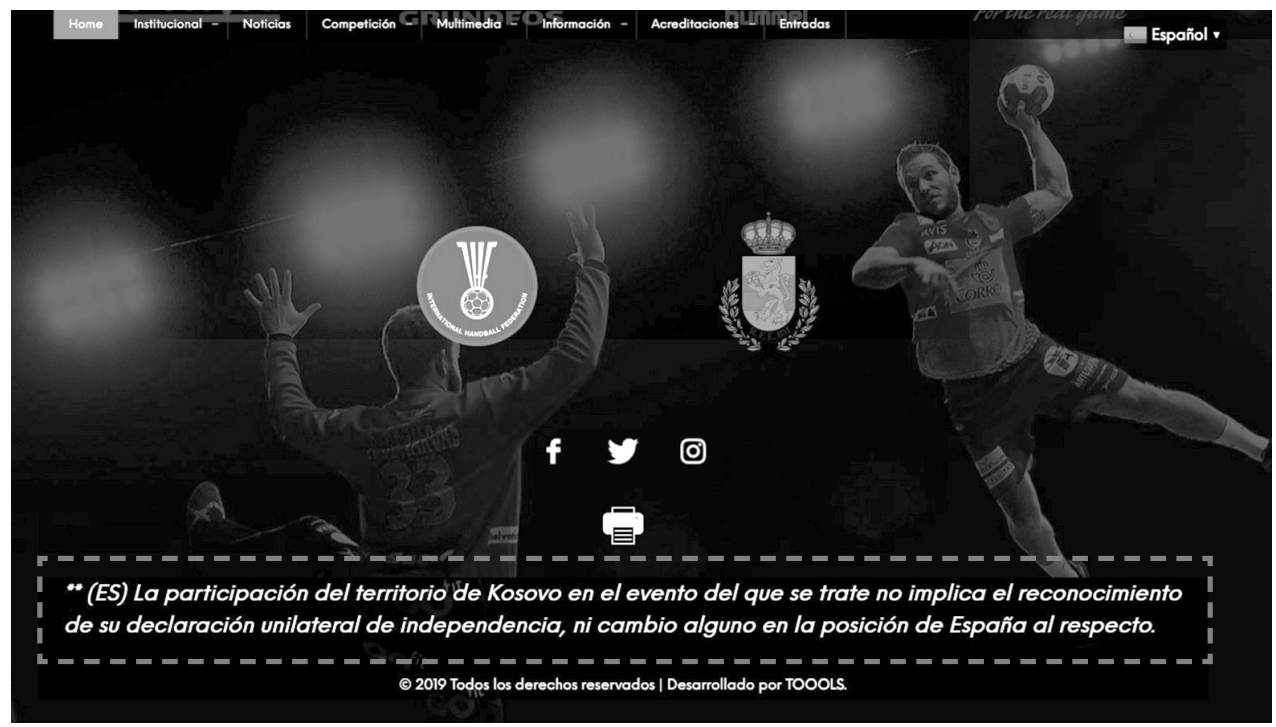

Source: IHF Men's Junior U21 (2019)

No matter what the agreements or policies say, every time Kosovo (either as individual athletes or as a team) has had to participate in sporting competitions hosted in Spain, the diplomatic controversy shows up again. A few months after the football dispute, a new episode took place. The cities of Vigo and Pontevedra (Galicia) served as venues for the 2019 Men's Junior World Handball Championship, from 16 to 28 July. The Balkan side was the last one to get qualified. This meant that the tournament's organising committee - the Spanish Handball Federation (RFEB) and the International Handball Federation (IHF) - had to negotiate with the Spanish authorities the way Kosovo would participate.

10 This measure does not apply to countries where an exclusion has been decided by the UEFA Executive Committee on security reasons, such as Serbia and Bosnia and Herzegovina. 
Initially, the Ministry of Foreign Affairs had set up a series of conditions to limit the exhibition of Kosovan symbols. Once again, the display of the flag and the play of the anthem were not allowed. In fact, during the draw for the group stage, Kosovo was depicted with the IHF's logo rather than its national banner as was the case of the other sides. After noticing it, the IHF threatened to withdraw the hosting rights for the 2021 Women's World Handball Championship due to take place in Catalonia and the Region of Valencia as well as an economic penalty. With that warning surrounding a new fiasco to the country's aspirations to become an international sporting hub, several administrations started some talks. Apart from the Ministry and the RFEB, CSD and COE also got involved. On 9 July, in other words just seven days before the tournament's kick off, the Ministry of Foreign Affairs was notified that Kosovo could participate in equal conditions to the rest of competitors. This implied the waving of the Balkan flag in the court and its anthem performed before every game.

Eventually, the championship went ahead with no restriction. However, there was an aspect that did not go unnoticed to the organisers. Back to the CSD's conditions explained above, this institution orders every federation, national and international alike, to show a warning message in the corresponding websites. Thus, the official site of this event published the following post: 'The participation of the territory of Kosovo in this event does not imply the recognition of its unilateral declaration of independence, or any change of the stand of Spain in that regard' (see Picture 2). Once again, we observe a systematic calculation from Madrid to give no room for any potential recognition of Kosovo as a state.

\section{Conclusion}

The acceptance of Kosovo into the different sporting international federations mainly epitomised with its full membership within the IOC as of 2014 - has opened a new scenario for its diplomatic relations with Spain. The potential participation of Kosovo in tournaments held in the Iberian country has pushed the Spanish Government to consider sport as a field of intervention for its political stand on Pristina. Thus, the practices and narratives employed by the Spanish public authorities regarding the presence of Kosovan athletes on its soil are not in vain. These are aligned with and form part of a broader policy of non-recognition of the Balkan territory as a state.

Madrid has set up a systematic strategy to give no room for a potential understanding of Kosovo as sovereign. It is in this sense how we comprehend its strict approach when dealing with administrative affairs. Athletes are considered as performers of the Kosovan state by carrying this specific passport (which Spain does not recognise either). Consequently, the corresponding documentation to enter the country is sealed in a sheet aside. Although this 
formula is not only used with this particular country, it aims at placing Kosovo in a different scale, that of the exceptionality. Besides, every accusation of no collaboration or wrongdoing (such as not issuing the visas for the 2018 World Karate Championships in Madrid) has been quickly denied by arguing a rigid interpretation of the law.

The same goes for the symbolic clashes. Understood as a representation of the state, the potential display of Kosovo's national flag, anthem and emblems is perceived as a concession in sovereign terms. Hence, we read the initial measures adopted as pretending to downgrade any such status whatsoever. Here too, the Spanish authorities have implemented a strict use of the rules by referring to the Balkan nation as Kosovo Olympic Committee (in fact NOCs and federations are the ones participating in the tournaments), or reminding them that the Olympic Charter states the utilisation of any flag, not necessarily the national one. As we can see, this is not the case with the rest of the competitors, thus reinforcing Spain's strategy of power.

The international pressure applied by sporting governing bodies (IOC, federations, etc.) on the Spanish authorities - mainly the threats to stop awarding events to Spain - has eased certain policies against Kosovar teams. Notwithstanding, the Iberian government has come out with new deliberated actions (such as the obligation to include banners on tournaments' websites stressing its non-recognition of Kosovo's statehood) looking at minimising, if not erasing, any sign of political change on the topic.

Supplementary, we highlight that Madrid's attitude towards the Balkan country must be understood as part of a dialectic relation between its foreign policies (membership of the EU and the bilateral relationships with Serbia) and its internal ones. The latter refers, specifically, to the nationalist claims from Catalonia and the Basque Country. The studied events have taken place in a period where these demands have been on the rise, particularly in Catalonia. Let us not forget that Catalonia's Regional Council declared its unilateral independence from Spain in October 2017. As Zákravský (2018) points out, sport has played a relevant role in these challenges. The effort to officialise their national teams has been a constant among the nationalist parties of both territories. Actually, the Partido Nacionalista Vasco (Basque Nationalist Party) included this issue in 2018 as part of its support to the current coalition ruling the Spanish government. Therefore, any concession given to Kosovo could be used by these peripheral movements to intensify their requests. The performativity of non-recognition of Kosovo as a state in and around the stadium proves wrong that traditional assumption that sport and politics should not mix (Houlihan - Zheng 2015). The practices and discourses utilised by the Spanish public authorities in this regard show that sport and politics are intertwined given their social nature. Therefore, although not mandatorily reciprocal, they are far from being independent terrains. 


\section{References}

ABC (2018): 'El COI pide a España respeto para los deportistas de Kosovo [IOC asks Spain to respect Kosovan athletes]', $A B C$ (13 November): available at: https://www.abc.es/deportes/abci-pide-espana-respeto-para-deportistas-kosovo-201811131846_noticia.html (1 February, 2021).

Aldecoa, Francisco - Keating, Michael (1999): Paradiplomacy in Action. The Foreign Relations of Subnational Governments, Frank Cass Publishers.

Aquino, Mariel (2017): A Panther Among Lions: Iñaki Williams, Race and Basque Identity at Athletic Club de Bilbao. Studia Iberica et Americana 4: 119-136.

Barker, Philip (2018): 'Spanish Government forced Kosovo not to parade national flag at Mediterranean Games Opening Ceremony', Inside the Games (6 July): available at: https://www. insidethegames.biz/articles/1067152/spanish-government-forced-kosovo-not-to-parade-national-flag-at-mediterranean-games-opening-ceremony (1 February, 2021).

Barston, Ronald P. (1988/2006): Modern Diplomacy, Pearson Education Limited.

Borgen, Christopher J. (2010): From Kosovo to Catalonia: Separatism and Integration in Europe. Goettingen Journal of International Law 2 (3): 997-1033. https://doi.org/10.3249/1868-15812-3-borgen

Brentin, Dario - Tregoures, Loïc (2016): Entering Through the Sport's Door? Kosovo's Sport Diplomatic Endeavours Towards International Recognition. Diplomacy \& Statecraft 27 (2): 360-378. https://doi.org/10.1080/09592296.2016.1169799

Brownell, Susan (2008): 'Could China Stop Taiwan from Coming to the Olympic Games?' History News Network (14 July): available at http://historynewsnetwork.org/article/51398 (31 January, 2021).

Butler, Judith (1990/2007): Gender Trouble. Feminism and the Subversion of Identity, Routledge.

Castan Pinos, Jaume - Sacramento, Jeremy (2019): L'Ètat contre-attaque: un examen de la contra-paradiplomatie espagnole en Catalogne (2012-2017). Relations Internationales 179 (3): 95-111. https://doi.org/10.3917/ri.179.0095.

Cifuentes, Pedro (2017): 'El COE contradice al Gobierno: invita a Kosovo a los Juegos de Tarragona [COE disagrees with the Government: Kosovo invited to the Tarragona Games]', El Español (25 September): available at: https://www.elespanol.com/deportes/20170921/248475769_0. html (1 February, 2021).

Congress of Deputies (2018): 'Government response. (184/17515) Questions for written answer to the Government', Government of Spain (4 January): available at: https://www.congreso. es/entradap/l12p/e6/e_0068086_n_000.pdf (31 January, 2021).

Congress of Deputies (2019): 'Government response. (184/40807) Questions for written answer to the Government', Government of Spain (16 January): available at: https://www.congreso. es/entradap/12p/e12/e_0120907_n_000.pdf (31 January, 2021).

Cruz, Marisa - Díaz-Guerra, Iñako (2018): 'Sánchez autoriza a Kosovo a competir bajo su bandera [Sánchez allows Kosovo to compete under its flag]', El Mundo (14 November): available at: https://www.elmundo.es/deportes/mas-deporte/2018/11/14/5bec5b8fe2704e04838b4655. html (1 February, 2021). 
Díez Romero, Javier (2013): El conflicto de Kosovo en la prensa española: del interés al olvido. Historia y Comunicación Social 18 (Special Number): 601-613. https://doi.org/10.5209/rev_ HICS.2013.v18.44267.

EFE Agency (2018): ‘España recuerda al COI que facilita la participación de kosovares aunque no reconozca su independencia [Spain reminds IOC it eases participation of Kosovans even if independence not recognized]', El Mundo (13 November): available at: https://www.elmundo. es/deportes/mas-deporte/2018/11/13/5beb4680268e3eba338b462a.html (1 February, 2021).

Elgenius, Gabriella (2011): The Politics of Recognition: Symbols, Nation Building and Rival Nationalism. Nations and Nationalism 17 (2): 396-418. https://doi.org/10.1111/j.1469-8129.2010.00482.x

El Periódico de Catalunya (2018): 'El COI ya habla con las federaciones para que excluyan a España si no reconoce a Kosovo [IOC in talks with federations to exclude Spain if Kosovo not recognised]', El Periódico de Catalunya (13 November): available at: https://www.elperiodico. com/es/deportes/20181113/coi-habla-federaciones-excluyan-espana-kosovo-7144088\# (1 February, 2021).

Ferrero-Turrión, Ruth (2020a): Los dilemas de la UE y España ante balcanes Occidentales. Instituto Español de Estudios Estratégicos: available at: http://www.ieee.es/contenido/noticias/2020/10/DIEEEO121_2020RUTFER_Balcanes.html (10 December 2020).

Ferrero-Turrión, Ruth (2020b): The Consequences of state Non-Recognition: The Cases of Spain and Kosovo. European Politics and Society. https://doi.org/10.1080/23745118.2020.1762958.

Gauthier, Ryan (2018): Constructing Statehood Through Sport: Football, Kosovo, and the Court of Arbitration for Sport. The Canadian Yearbook of International Law 56: 220-257. https:// doi.org/10.1017/cyl.2019.4.

Gilboa, Avi - Bodner, Ehud (2009): What Are Your Thoughts when the National Anthem Is Playing? An Empirical Exploration. Psychology of Music 37 (4): 459-484. https://doi. org/10.1177/0305735608097249.

Gil Araújo, Sandra (2002): Fútbol y Migraciones. La Sentencia Bosman en el Proceso de Construcción de la Europa Comunitaria (Crónicas desde España). Migraciones Internacionales 1 (3): 55-78. https://doi.org/10.17428/rmi.v1i3.1283.

Giulianotti, Richard (1999): Football. A Sociology of the Global Game, Polity Press.

Giulianotti, Richard - Collison, Holly - Darnell, Simon - Howe, David (2016): Contested States and the Politics of Sport: The Case of Kosovo - Division, Development, and Recognition. Policy and Politics 9 (1): 121-136. https://doi.org/10.1080/19406940.2016.1217251.

Government of Spain (2018a): 'Comunicado 163. Participación de deportistas kosovares en eventos olímpicos celebrados en España [Press release 163. Participation of Kosovar athletes in Olympic events held in Spain]', Ministry of Foreign Affairs (13 November): available at: http:// www.exteriores.gob.es/Portal/es/SalaDePrensa/Comunicados/Paginas/2018_COMUNICADOS/20181113_COMU163.aspx (31 January, 2021).

Government of Spain (2018b): ‘Comunicado 164. Participación de deportistas kosovares en eventos olímpicos celebrados en España [Press release 164. Participation of Kosovar athletes in Olympic events held in Spain]', Ministry of Foreign Affairs (14 November): available at: 
http://www.exteriores.gob.es/Portal/es/SalaDePrensa/Comunicados/Paginas/2018_COMUNICADOS/20181114_COMU164.aspx (31 January, 2021).

Government of Spain (2019): 'Ley del Deporte [Sports Law]', available at: https://www.csd.gob. es/es/csd/organizacion/legislacion-basica/ley-del-deporte (31 January, 2021).

Herrero, Nacho (2016): ‘El CSD avisa que Doellman no podrá jugar como kosovar en la Liga Endesa [CSD warns that Doellman could not play as Kosovan in Liga Endesa]', Mundo Deportivo (21 June): available at: https://www.mundodeportivo.com/baloncesto/ acb/20160621/402660217027/el-csd-avisa-que-doellman-no-podra-jugar-como-kosovar-en-la-liga-endesa.html (1 February, 2021).

Hobsbawm, Eric J. (1992): Nations and Nationalism since 1780, Cambridge University Press.

Houlihan, Barrie - Zheng, Jinming (2015): Small States: Sport and Politics at the Margin. International Journal of Sport Policy \& Politics 7 (3): 329-344. https://doi.org/10.1080/19406940. 2014.959032.

IHF Men's Junior U21 (2019): 'Home', International Handball Federation: available at https:// spainhandball19.com/\# (8 February, 2021).

IOC (2018): 'Joint statement of the IOC and the Spanish Olympic Committee', News (14 November): available at: https://www.olympic.org/news/joint-statement-of-the-ioc-and-the-spanish-olympic-committee (31 January, 2021).

IOC (2020): 'Olympic Charter', IOC (17 July): available at: https://stillmedab.olympic. org/media/Document\%20Library/OlympicOrg/General/EN-Olympic-Charter.pdf\#_ ga=2.22469048.2078030412.1612090898-523272454.1612090898 (31 January, 2021).

Juventeny, Sílvia (2019): Much 'More than a Club': Football Club Barcelona's Contribution to the Rise of a National Consciousness in Catalonia (2003-2014). Soccer \& Society 20 (1): 103-122. https://doi.org/10.1080/14660970.2016.1267624.

Ker-Lindsay, James (2020): The counter-diplomacy of state recognition, in Visoka, Gëzim - Doyle, John - Newman, Edward, eds., Routledge Handbook of State Recognition. 295-305, Routledge.

Kosovo Olympic Committee (2018): 'NOC KOSOVO @NOCKOSOVO', Twitter (21 June): available at: https://twitter.com/NOCKOSOVO/status/1009759279312711680 (2 February, 2021).

Lambea, Alberto (2018): ‘Decepción en la halterofilia tras perder el Europeo: “En un deporte más potente, estaría arreglado" [Disappointment in weightlifting after losing the European Championships: "In a more powerful sport, it would be solved"]', El Mundo (24 April): available at: https://www.elmundo.es/deportes/mas-deporte/2018/04/24/5adf5d05e2704efe52 8b4848.html (1 February, 2021).

Lin, Chien-Yu - Lee, Ping-Chao - Nai, Hui-Fang (2008): Theorizing the Role of Sport in State-Politics. International Journal of Sport and Exercise Science 1 (1): 23-32.

Maura, Andrea (2013): España imagina los Balcanes. Construyendo puentes hacia el 'otro europeo' en Yugoslavia y Bosnia y Hercegovina. Revista de Paz y Conflictos 6: 173-189.

Maura, Fernando - Del Campo, Sergio (2017): 'A la mesa del Congreso de los Diputados [To the General Committee of the Congress of Deputies]', Grupo Parlamentario Ciudadanos (28 September): available at: https://www.congreso.es/entradap/12p/e4/e_0048651_n_000. pdf (2 February, 2021). 
Mackay, Duncan (2016): 'Kosovo promised Spanish Government will not block participation in 2017 Mediterranean Games', Inside the Games (19 May): available at: https://www.insidethegames.biz/articles/1037605/kosovo-promised-spanish-government-will-not-block-participation-in-2017-mediterranean-games (1 February, 2021).

McGuinnes, Mike (2021): The Kosovo Football Team, National Symbols and Identity: 'A Team of Eleven Named Men', in O'Brien, Jim - Holden, Russell - Ginesta, Xavier, eds., Sport, Globalisation and Identity: New Perspectives on Regions and Nations. 52-68, Routledge.

Morgan, Liam (2018a): 'Exclusive: WKF President warns Spain's hosting of future events in jeopardy over Government stance on Kosovo', Inside the Games (9 November): available at: https://www.insidethegames.biz/articles/1072065/exclusive-wkf-president-warns-spains-hosting-of-future-events-in-jeopardy-over-government-stance-on-kosovo (1 February, 2021).

Morgan, Liam (2018b): 'IOC tell International Federations not to award events to Spain unless Government provides guarantees on Kosovo participation', Inside the Games (11 November): available at: https://www.insidethegames.biz/articles/1072170/ioc-tell-international-federations-not-to-award-events-to-spain-unless-government-provides-guarantees-on-kosovo-participation (1 February, 2021).

Murray, Stuart - Pigman, Geoffrey A. (2014): Mapping the Relationship between International Sport and Diplomacy. Sport in Society 17 (9): 1098-1118. https://doi.org/10.1080/17430437.2 013.856616.

Nieto, Antonio (2018): ‘España se queda sin un Europeo de halterofilia porque no reconoce a Kosovo [Spain loses a European Weightlifting Championship because Kosovo not recognised]', El País (23 April): available at: https://elpais.com/deportes/2018/04/23/actualidad/1524497268_113928.html (1 February, 2021).

Oficina dels Jocs Mediterranis Tarragona 2018 (2018): 'Countries', Oficina dels Jocs Mediterranis Tarragona 2018: available at: https://results.tarragona2018.cat/en/countries (8 February, 2021).

Ojeda, Darío (2018): 'La amenaza deportiva (del COI) a España por su problema con Kosovo [The sporting threat (from the IOC) to Spain for its problem with Kosovo]', El Confidencial (12 November): available at: https://www.elconfidencial.com/deportes/2018-11-12/kosovo-espana-comite-olimpico-competiciones_1643714/(1 February, 2021).

Oliver, Brian (2018): 'Exclusive: Spain loses weightlifting championships because of political stance over Kosovo', Inside the Games (23 April): available at: https://www.insidethegames. biz/articles/1064262/spain-loses-weightlifting-championships-because-of-political-stance-over-kosovo (1 February, 2021).

Pulleiro, Carlos (2015): Fútbol y política: reflexiones de una relación compleja a través del festival de cine Thinking Football. Materiales para la Historia del Deporte 13: 37-46.

Pulleiro, Carlos (2020): National recognition and power relations between states and sub-state governments in international sport. International Journal of Sport Policy and Politics 12 (2): 189-205. https://doi.org/10.1080/19406940.2019.1706620.

Ràdio Associació de Catalunya (2018): 'El COI advertix Espanya de 'les conseqüències' de negar el visat als esportistes de Kosovo [ $\mathrm{OCC}$ warns Spain of 'the consequences' of denying visas 
to athletes from Kosovo]', RAC1 (13 February): available at: https://www.rac1.cat/programes/ el-mon/20180213/44753095681/jocs-del-mediterrani-jjoo-jocs-olimpics-pere-miro-kosovo-mendez-de-vigo.html (1 February, 2021).

Raento, Pauliina - Watson, Cameron J. (2000): Gernika, Guernica, Guernica? Contested meanings of a Basque Place. Political Geography 19 (6): 707-736. https://doi.org/10.1016/S09626298(00)00002-0.

Saumell, Octavi (2018): 'España dará visado a Kosovo para los Juegos de Tarragona [Spain will issue visa to Kosovan athletes for the Tarragona Games]', Diari de Tarragona (13 February): available at: https://www.diaridetarragona.com/tarragona/Espana-dara-visado-a-Kosovo-para-los-Juegos-de-Tarragona--20180213-0082.html (1 February, 2021).

Skalski, Paul D. - Neuendorf, Kimberley A. - Cajigas, Julie A. (2017): Content Analysis in the Interactive Media Age, in Neuendorf, Kimberley, ed., The Content Analysis Guidebook. Second edition, 201-403, SAGE Publications.

The European Parliament and the Council (2009): 'Regulation (EC) No 810/2009 establishing a Community Code on Visas', Official Journal of the European Union (13 July): available at: https://eur-lex.europa.eu/legal-content/EN/TXT/HTML/?uri=CELEX:32009R0810 \& from=ES \#d1e974-1-1 (31 January, 2021).

UEFA (2019): 'UEFA to ask FIFA/IFAB for new concussion protocol', UEFA (29 May): available at: https://www.uefa.com/insideuefa/about-uefa/news/0251-0f8e6c171bac-f18e94862ff1-1000-uefa-to-ask-fifa-ifab-for-new-concussion-protocol/ (31 January, 2021).

UEFA (2020): 'FIFA World Cup 2022. Qualifying draw procedure', UEFA (17 June): available at: https:// www.uefa.com/MultimediaFiles/Download/competitions/WorldCup/02/64/22/19/2642219_ DOWNLOAD.pdf (27 January, 2021).

Vila, Pol - Demjaha, Agon (2019): Kosovo-Spain Relations and the Dilemmas on the Problem of Non-Recognition. SEEU Review 14 (1): 69-90. https://doi.org/10.2478/seeur-2019-0005.

Xuclà i Costa, Jordi (2018): 'A la mesa del Congreso de los Diputados [To the General Committee of the Congress of Deputies]', Partit Demòcrata (14 November): available at: https://www. congreso.es/entradap/112p/e11/e_0112446_n_000.pdf (2 February, 2021).

Zabalo, Julen - Odriozola, Onintza (2017): The Importance of Historical Context: A New Discourse on the Nation in Basque Nationalism? Nationalism and Ethnic Politics 23 (2): 134-154. https:// doi.org/10.1080/13537113.2017.1311140.

Zákravský, Jiř́ (2018): A Symbolic Clash among the National Identities in the Basque Autonomous Community: Political Parties, Twitter and UEFA European Championship 2016. Politické vedy 21 (4): 30-48. https://doi.org/10.24040/politickevedy.2018.21.4.30-48.

Fernando Gutiérrez-Chico is Research Fellow within the Group 'Sport, Culture and Society' (DEPCyS), University of La Laguna, Canary Islands, Spain., Ph.D. studied in Social Sciences, with research focus on Anthropology of Sport, at the University of Salamanca, Journalism Studies at the Basque Country University. Email: fgutierrezchico@gmail.com. 
Iñigo González-Fuente is Senior Lecturer of Sociology at the Faculty of Education, University of Cantabria, Spain., Ph.D. studied in Social Sciences, with research focus on Political Anthropology, at the University of Salamanca; Political Sciences at the Basque Country University. Email: inigo.gonzalez@unican.es. 